Nikolina Kolendo*, https:/ / orcid.org/0000-0003-0982-7138

Helena Wronka*, https:// orcid.org/0000-0002-5259-3691

*Instytut Psychologii WFCH

Uniwersytet Kardynata Stefana Wyszyńskiego

$w$ Warszawie

\title{
Depresja wśród dzieci i młodzieży - przebieg, leczenie oraz wpływ na system rodzinny
}

\section{Depression in children and adolescents - its course, treatment and impact on the family system}

https://doi.org/10.34766/fetr.v45i1.461

\begin{abstract}
Abstrakt: Celem artykułu jest omówienie problematyki występowania depresji u dzieci i młodzieży oraz jej wpływu na system rodzinny. Analizie zostały poddane w szczególności objawy i rodzaje depresji występującej u dzieci i młodzieży, jej wpływ na funkcjonowanie rodziny oraz zastosowanie terapii i psychoedukacji w celu poprawy funkcjonowania systemu rodzinnego.

Słowa kluczowe: depresja, dzieci, młodzież, system rodzinny
\end{abstract}

Abstract: The article focuses on the problem of depression in children and adolescents and its impact on the family system. The analysis concerns in particular the symptoms and types of depression occurring in children and adolescents and its impact on family functioning. The article also highlights the use of therapy and psychoeducation to improve the functioning of the family system.

Keywords: depression, children, adolescents, family system

\section{Wprowadzenie}

Depresja jest zjawiskiem coraz częściej występującym w grupie dzieci i młodzieży. Badania wskazują, że na depresję $\mathrm{z}$ roku na rok choruje coraz więcej dzieci (por. np. Birmaher, Arbelaez, Brent, 2002; Bomba, Modrzejewska, 2006; Modrzejewska, Bomba, 2006a, 2006b, 2010; Przybylska, 2016; Raczkowski, 2017; Wendołowska, 2017; Januszewska, 2020).

Już kilkanaście lat temu Jolanta Rabe-Jabłońska (2007) słusznie zauważyła, że specjaliści zajmujący się zaburzeniami afektywnymi, występującymi u dzieci i młodzieży, posiadają niezadowalający poziom wiedzy na temat objawów depresji. Dziś nadal problem ten jest aktualny, nadal podstawą do rozpoznania depresji w grupie dzieci i młodzieży są objawy klasyfikowane w oparciu o kryteria diagnozowania depresji osób dorosłych.

\section{Objawy depresji u dzieci i młodzieży}

Do drugiej połowy XX wieku temat depresji dzieci i młodzieży znajdował się na dalszym planie. Wśród psychiatrów toczyły się spory na temat tego, czy depresja 
rzeczywiście występuje przed dorosłością, bowiem wielu z nich uważało, iż depresja nie może występować $\mathrm{w}$ tak młodym wieku, ze względu na brak $\mathrm{w}$ tym okresie pełnej dojrzałości emocjonalnej. Choć w latach 70 . XX wieku rozpoczęto prace dotyczące depresji młodzieńczej, jeszcze w latach 80. część psychologów i psychiatrów twierdziła, iż nie należy poświęcać czasu na badania w tym zakresie. Przeważało stanowisko, iż depresja w okresie młodzieńczym jest naturalnym etapem rozwoju człowieka. Jednakże, pomimo znacznych postępów w rozwoju nauki w tym zakresie, temat depresji dzieci i młodzieży wymaga nadal nieustannego pogłębiania, ponieważ wiedza na ten temat jest wciąż niewystarczająca, zwłaszcza w porównaniu z wiedzą o depresji dorosłych (Raczkowski, 2017).

Depresja młodzieńcza (Bomba, 2007) charakteryzuje się zaburzeniami w obszarze emocji, nastroju i zachowań, także zaburzeniami w sferze poznawczej. Już podczas pierwszych badań dotyczących depresji u dzieci i młodzieży zauważono, że charakterystyczne dla niej jest również nasilenie tendencji ukierunkowywania agresji ku sobie (por. np. Kępiński, 2014).

Objawy depresji u dzieci i młodzieży mogą mieć różne stopnie intensywności oraz przebiegać w różnych połączeniach. Zaburzenia w sferze emocji ujawniają się najczęściej pod postacią nasilonego lęku przed przyszłością oraz agresji, natomiast nieprawidłowości w nastroju objawiają się jego obniżeniem o różnym stopniu intensywności oraz różnym zabarwieniu emocjonalnym (Bomba, 2007). Nieprawidłowości w sferze poznawczej zazwyczaj zaznaczają się $\mathrm{w}$ funkcjonowaniu szkolnym. Dziecko przejawia trudności w nauce, skupieniu, zaczyna przeżywać coraz więcej niepowodzeń. Następstwem tych problemów jest obniżenie poczucia własnej wartości dziecka, a także przekonanie o swojej nieskuteczności. Pojawiają się także zaburzenia aktywności.

Te objawy mogą być niewidoczne w sytuacji, gdy są tłumione przez różnorodne zaburzenia zachowania, począwszy od rezygnacji z wykonywania obowiązków domowych czy chodzenia do szkoły, aż do podejmowania zachowań ryzykownych, takich jak spożywanie substancji psychoaktywnych czy ryzykowne zachowania seksualne. Dodatkowo w przebiegu depresji u dzieci i młodzieży mogą pojawić się takie objawy jak: zamknięcie w sobie, brak motywacji do działania, a także myśli i tendencje samobójcze (Przybylska, 2016).

\section{Rodzaje depresji dzieci i młodzieży}

J. Bomba (2007) wyróżnił cztery rodzaje depresji młodzieńczej: depresję czysta, depresje $z$ rezygnacja, depresje z niepokojem oraz depresje hipochondryczna. Depresja czysta nazwał zaburzenie, które charakteryzuje się obniżeniem nastroju oraz napędu, pojawieniem się nieokreślonego lęku oraz lęku przed przyszłością. Depresja z rezygnacja to zaburzenie, które obejmuje także trudności w nauce, poczucie braku sensu życia oraz myśli, tendencje i próby 
samobójcze. $W$ depresji z niepokojem, obok objawów podstawowych, pojawiają się charakterystyczne dla tego zaburzenia wahania nastroju oraz zachowania autodestrukcyjne. Depresja hipochondryczna, charakteryzuje się objawami w postaci somatycznej. Ponadto, chory wykazuje hipochondryczne skupienie na własnym ciele (tamże).

Obecnie jednak odchodzi się od konstruktu depresji młodzieńczej, ze względu na niejasność granic tego pojęcia (Bomba, 2009). Rozpoznając depresję u dzieci i młodzieży traktuje się ją jako formę zaburzeń afektywnych, co jest zgodne z obecnie obowiązującym systemem klasyfikacji (tamże).

A. Kępiński (2010) rozróżnia cztery rodzaje depresji młodzieńczej. Pierwszą z nich jest depresja apatyczno-abuliczna, która cechuje się biernością, pustką, brakiem radości oraz odczuciem braku sensu życia. Kolejną jest depresja buntownicza, dla której charakterystyczne jest zaostrzenie zachowań typowych dla okresu buntu młodzieńczego, występowanie zachowań agresywnych, również autoagresji oraz niskie poczucie własnej wartości. Trzecia postać depresji to depresja rezygnacyjna, dla której typowy jest brak wiary w siebie, rezygnacja z zainteresowań, brak planów życiowych oraz pesymistyczna wizja siebie i swojej przyszłości. Ostatnią jest postać labilna depresji, która charakteryzuje się silnymi wahaniami nastroju, z wyraźnymi tendencjami samobójczymi w fazie obniżonego nastroju (tamże).

Często dzieci chorujące na depresję wykazują objawy przeciwne do typowych objawów depresji. Ten rodzaj depresji nazywany jest depresja atypowa, a charakterystyczne dla niej objawy to: nadmierna senność oraz łaknienie, widocznie gorsze samopoczucie wieczorem oraz reaktywność nastroju (Rabe-Jabłońska, 2007).

Dzisiaj młodociani mają dostęp do przeróżnych źródeł, które popularyzują trend fascynacji śmiercią lub powodują spadek ich samooceny (Tomaszewska, 2012), co jeszcze bardziej pogłębia problem.

\section{Modele depresji}

Istnieje wiele modeli próbujących wyjaśnić mechanizm powstawania depresji.

$\mathrm{W}$ nurcie psychodynamicznym próbuje go tłumaczyć teoria relacji z obiektem (Radziwiłłowicz, 2010). Wynika z niej, że depresja jest skutkiem frustracji, jakich dziecko doświadczyło we wczesnej relacji z opiekunem, który nie odpowiadał na potrzeby dziecka w wystarczającym stopniu, co spowodowało wykształcenie się pewnych cech osobowości sprzyjających powstawaniu depresji (tamże; por. także: Segal, 2006).

Z kolei w nurcie poznawczym proces powstawania depresji tłumaczy między innymi teoria depresji zaproponowana przez A. Becka. Klasyczny model depresji w ujęciu Becka (1967; 1976, za: Hammen, 2006) zakłada, że aby pojawiła się depresja muszą zajść wydarzenia, które powodują aktywizację pewnego typu automatycznych myśli zawierających przekonania na temat siebie i innych. Niesie to za sobą konsekwencje 
w postaci pojawiających się objawów depresyjnych, takich jak spadek nastroju, aktywności, itd. W przypadku depresji automatyczne myśli stają się tzw. schematami poznawczymi, co oznacza, że zaczynają stanowić stały sposób myślenia o osobie, innych i świecie, przez co objawy depresyjne ulegają nasileniu (tamże).

Kolejnymi modelami próbującymi wyjaśnić mechanizm powstawania depresji są modele interpersonalne, które zakładają, że jest ona efektem próby dostosowania się jednostki do otoczenia, w którym ona funkcjonuje, do środowiska, które przejawia cechy niesprzyjające prawidłowemu funkcjonowaniu. Modele interpersonalne proponują takie ujęcie depresji, której objawy pojawiają się $\mathrm{w}$ wyniku niezaspokojenia potrzeb jednostki dotyczących relacji z innymi. Istotną rolę odgrywają tutaj: niska jakość więzi emocjonalnych, brak oparcia oraz poczucia bezpieczeństwa oraz wiązane $\mathrm{z}$ tym poczucie osamotnienia, a także trudności w kontaktach z innymi, np. w komunikacji (Radziwiłłowicz, 2010).

Warto podkreślić także systemowe podejście do depresji dzieci i młodzieży. Teorie systemowe zakładają, iż istnieje złożona sieć zjawisk i relacji, które oddziaływują wzajemnie na wszystkich członków systemu, jakim jest rodzina (Sęk, 2008). Nieprawidłowe relacje w systemie rodzinnym oraz różne stresujące, traumatyczne wydarzenia, mogą wpływać na wystąpienie symptomów depresyjnych u dzieci i młodzieży. Na ich pojawienie się może wpływać brak poczucia bezpieczeństwa, utrata członka rodziny, występujące $\mathrm{w}$ rodzinie konflikty, czy zaburzenia psychiczne rodziców (Radziwiłłowicz, 2010).

Na uwage zasługuje także model zaproponowany przez MacCaulay'a, Pavlidisa i Kendalla (2001), którzy starali się stworzyć kompleksowe ujęcie depresji. Zaproponowali model, który integruje podejście poznawcze, systemowe oraz psychodynamiczne. W tym ujęciu na wystąpienie objawów depresji mogą wpływać takie czynniki, jak: predyspozycja genetyczna, odrzucenie rodzicielskie, brak wsparcia rodzica oraz zaburzenia komunikacji wewnątrzrodzinnej. Pojawiające się na różnych etapach życia zmiany i zadania rozwojowe także zwiększają ryzyko wystąpienia depresji (por. także: Radziwiłłowicz, 2010). Ważnymi czynnikami są także trudne indywidualne doświadczenia we wczesnym okresie rozwoju, jak również niewłaściwe relacje $\mathrm{z}$ rówieśnikami (Wendołowska, 2017). Na możliwość wystąpienia objawów depresyjnych również wpływają zaburzenia regulacji emocji oraz rozwój nieadapcyjnego radzenia sobie ze stresem (Michalska-Leśniewicz, Gruszczyński, 2010). Trzeba podkreślić, że czynniki te nie są rozłączne, a oddziałują na siebie wzajemnie, mogą występować w różnych konfiguracjach i nasileniach.

\section{Depresja a system rodzinny}

Pojawienie się depresji u dziecka czy nastolatka całkowicie zmienia dotychczasowe funkcjonowanie rodziny (Ambroziak, Kołakowski, Siwek, 2018). Osoba młoda, mieszkająca z bliskimi jest z nimi silnie związana emocjonalnie. Oznacza to, że wystąpienie choroby 
u jednego z członków rodziny będzie miało ogromny wpływ na pozostałych członków rodziny. Stąd też cała rodzina musi przygotować się na zmiany, które wystąpią w związku $\mathrm{z}$ chorobą. Zazwyczaj wiąże się to ze stresem, ze zmęczeniem lub sfrustrowaniem, ale także z podwyższeniem kosztów, które musi ponieść rodzina. Często jest tak, że choroba przyczynia się do nawarstwiania się konfliktów, może nawet spowodować całkowity rozpad więzi rodzinnych (tamże).

Często rodzina ma problem z zauważeniem pierwszych objawów depresji u dziecka. Powstają problemy z komunikacją, ponieważ rodzice nie potrafią zrozumieć zachowania dziecka. Opiekunowie, chcąc trudną sytuację tłumaczą lenistwem, "złymi nawykami”, Czy też trudnym wiekiem. K. Ambroziak, A. Kołakowski, N. Siwek (2018) na podstawie modelu E. Kubler-Ross odnoszącego się do teorii etapów przeżywania choroby, opracowali etapy przystosowania się do choroby depresyjnej. Pierwszym z nich jest zaprzeczenie, które wiąże się $\mathrm{z}$ bagatelizowaniem problemu, wątpieniem $\mathrm{w}$ diagnozę lekarza czy poszukiwaniem innych wyjaśnień objawów. Drugim etapem, przez który przechodzą najbliżsi chorego dziecka, jest złość, w szczególności na otoczenie i specjalistów. Kolejny etap to targowanie się, w którym bliska rodzina robi wszystko, by nie okazało się, że dziecko jest chore. Następnie przychodzi etap obniżonego nastroju, który charakteryzuje się intensywnym rozmyślaniem, dlaczego to musiało spotkać właśnie mnie, smutkiem, żalem, drastycznymi wyobrażeniami konsekwencji choroby. Ostatnim i najważniejszym etapem jest akceptacja. Polega ona na przyjęciu do świadomości tego, że dziecko jest chore, co sprzyja obiektywnemu przyjrzeniu się chorobie oraz przyjęciu zaleceń specjalistów (tamże).

Po zaakceptowaniu choroby rodzina staje przed kolejnym trudnym zadaniem, jakim jest dostosowanie życia codziennego do występującej u dziecka depresji (Ambroziak, Kołakowski, Siwek, 2018). Chore dziecko trzeba otoczyć szczególną opieką oraz stale obserwować jego stan psychiczny. W związku z tym rodzice muszą całkowicie zmienić codzienność, w jakiej do tej pory funkcjonowali. Przykładowo, taka sytuacja może się wiązać $\mathrm{z}$ tym, że jeden z rodziców będzie musiał pójść zrezygnować z pracy. Bardzo ważne w tej sytuacji jest szukanie pozytywnych stron choroby. Jedną z nich może być zaprzestanie konfliktów czy wypracowanie jednomyślności rodziców w wielu sprawach, które sprzyjają zacieśnianiu się więzi rodzinnych. Członkowie rodziny zaczynają ze sobą rozmawiać, okazują sobie pozytywne uczucia, mimo że kiedyś przychodziło im to z trudem. Należy jednak być ostrożnym, ponieważ może to podtrzymywać depresję u dziecka. W pierwszym etapie leczenia całkowite skupienie na chorym dziecku jest oczywiste i zrozumiałe. Jednak przy leczeniu długoterminowym niezwykle ważne jest to, żeby zadbać o całą rodzinę. Wszystkie dzieci w rodzinie powinny otrzymywać od rodziców tyle samo troski, uwagi i czułości (tamże).

Młode osoby po zachorowaniu na depresję często zaniedbują codzienne obowiązki, głównie naukę. Jest to zrozumiałe, ponieważ depresja odbiera siły potrzebne do 
podejmowania wyzwań, czy radzenia sobie z problemami. Niezwykle ważne jest to, aby powrót do zdrowia wiązał się także $\mathrm{z}$ powrotem do funkcjonowania w rzeczywistości. Czasem zdarza się jednak, że dana osoba ma z tym duży problem (Ambroziak, Kołakowski, Siwek, 2018). Okres rekonwalescencji powinien być związany z obniżeniem wymagań, aby osoba po kryzysie psychicznym mogła w spokoju odzyskać siły. W przypadku młodego człowieka myśl o powrocie do dawnych obowiązków może budzić niechęć. Mogą też wystąpić obawy, że ponowne wejście w życie codzienne spowoduje nawrót choroby. Tego typu postawy mogą mieć bardzo poważne konsekwencje, np. powodować utratę kontaktu z grupą rówieśniczą, co przyczynia się do poczucia osamotnienia młodego człowieka. Opiekunowie powinni zachęcać dziecko do ponownego podjęcia codziennych obowiązków, zwracając przy tym uwagę na odpowiednie ich dostosowanie do jego możliwości (tamże).

\section{Terapia}

Terapia zaburzeń depresyjnych powinna zawierać $w$ sobie oddziaływania farmakologiczne i psychoterapeutyczne wraz z psychoedukacją pacjentów i ich rodzin. Obecnie jedną z najczęściej stosowanych metod oddziaływania jest terapia poznawczobehawioralna (Rabe-Jabłońska, 2007). Polega ona na skupianiu się na istotnych problemach jednostki poprzez nabywanie alternatywnych wzorców myślenia, co przyczynia się do poprawy jej funkcjonowania oraz komfortu psychicznego. W procesie zdrowienia psychoterapia może być prowadzona indywidualnie, grupowo oraz jako terapia rodzinna (Kołodziejek, 2008). Ze względu na to, że dysfunkcje w rodzinie mogą wpływać na wzmożenie objawów depresyjnych, także na pogarszanie relacji i funkcjonowania pozostałych członków rodziny, zastosowanie terapii rodzinnej odgrywa szczególną rolę $\mathrm{w}$ procesie zdrowienia. Podczas terapii rodzinnej członkowie rodziny pełnią funkcję współpacjentów bądź pacjentów, gdy sami rozpoczynają naukę nowych umiejętności i radzenia sobie z problemami (Stallard, 2006). Jeśli rodzice uczestniczą w nabywaniu umiejętności poznawczych przez dzieci, można uznać ich za współterapeutów. Natomiast $\mathrm{w}$ sytuacji, gdy rodzice pomagają $\mathrm{w}$ zastosowaniu $\mathrm{w}$ środowisku domowym nowych umiejętności nabytych podczas terapii, uznaje się ich za facylitatorów (tamże).

Ważnym elementem terapii jest psychoedukacja dziecka cierpiącego na depresję i jego rodziny. Jej głównym celem jest próba zwiększenia świadomości chorego i członków rodziny na temat depresji, możliwości wpływu na jej przebieg oraz pomoc w adaptacji do niej (Colom, 2011). Psychoedukacja w głównej mierze pomaga jej uczestnikom w adaptacji do wyzwań życia codziennego (Grabski, Mączka, Dudek, 2011). Poprzez rozpoznanie uczuć związanych z problemem uczestnicy terapii mają możliwość rozwinięcia zasobów, które mogą wykorzystać do poradzenia sobie z napotkanymi problemami. Ponadto, podczas działań psychoedukacyjnych podejmowane działania mające na celu zmianę przekonań 
uczestników dotyczących problemu, z którym się mierzą. Dzięki temu nie tylko sam chory, ale także jego najbliższe otoczenie jest $\mathrm{w}$ stanie lepiej zrozumieć problematykę choroby. $\mathrm{W}$ rezultacie $\mathrm{u}$ chorego i jego rodziny zmniejsza się lęk, wzrasta poczucie bezpieczeństwa i nadzieja na poprawę.

\section{Podsumowanie}

Problem pojawiającej się depresji wśród dzieci i młodzieży jest coraz bardziej zauważalny. Dzięki poruszaniu tego zagadnienia, także przez media, zaczynają się pojawiać szersze informacje na ten temat.

Żyjemy w trudnych czasach, w których kontrolę nad systemem wartości młodych ludzi zaczyna przejmować Internet. Wobec popularyzacji fascynacji śmiercią szczególną uwagę należy przywiązać do ochrony nieletnich przed tym niebezpiecznym zjawiskiem. Jednym z głównych środowisk chroniących dzieci przed różnego rodzaju zagrożeniami jest rodzina, która jest $\mathrm{w}$ stanie zapewnić dziecku bezpieczeństwo lub szczególną opiekę w przypadku wystąpienia choroby. Niezwykle ważną częścią walki z tą chorobą jest również odpowiednio dobrana terapia, a w skrajnych przypadkach także hospitalizacja.

Narastające zjawisko osamotnienia młodych ludzi, będące często przyczyną obniżenia nastroju czy depresji, określane jest dzisiaj jako swoistego rodzaju "znak czasu” (por. np. Krupa, 2013). Problem ten stawia przed rodzicami, nauczycielami, wychowawcami, czy psychologami poważne wyzwania związane $\mathrm{z}$ koniecznością przeciwdziałania temu zjawisku (por. np. Ryś, 2020).

I. Sikorska (2016, s. 215) podaje za A. Hartem, iż dzisiaj młodzi ludzie otrzymują „zbyt wiele $i$ zbyt wcześnie", w wielu sferach otrzymując "zbyt wiele dobrego", co prowadzi do nadmiaru stymulacji, ofert aktywności oraz konieczności udziału w wielu różnorodnych rankingach. A jednak w najważniejszych wymiarach ludzkiej egzystencji dotyczącej bliskich relacji otrzymują zbyt mało - miłości i więzi, doświadczając "za dużo stresu, a za mało rodziny".

W tym kontekście M. Ryś (2020) podkreśla znaczenie profilaktyki służącej budowaniu prawidłowych, ciepłych i bliskich relacji z innymi, odkrywaniu i kształtowaniu poczucia własnej wartości, a także odporności psychicznej dzieci, młodzieży, czy też rodziny jako całości. Warto więc organizować warsztaty, szkolenia dotyczące umiejętności właściwego zaspokajania potrzeb, pogłębiania umiejętności prawidłowej komunikacji, rozwiązywania konfliktów, radzenia sobie ze stresem. Ważne są także wszelkie działania, które pomogą młodym ludziom w wyzwalaniu radości życia, chęci i pasji działania, będą wzmacniać pragnienie rozwoju, będą pomagały w tworzeniu wspólnoty z innymi, opartej na głębokich więzach wyrażających się we współobecności, współrozumieniu, współodczuwaniu i współdziałaniu. 


\section{Bibliografia:}

Ambroziak, K., Kołakowski, A., Siwek, N. (2018). Nastolatek a depresja. Praktyczny poradnik dla rodziców i młodzieży, Gdańsk: Gdańskie Wydawnictwo Psychologiczne.

Birmaher, B., Arbelaez, C., Brent, D. (2002). Course and outcome of child and adolescent major depressive disorder, Child and Adolescent Psychiatric Clinics of North America, 11 (3), 619-637, https:/ / doi.org/10.1016/S1056-4993(02)00011-1.

Bomba, J. (1982). Depresja dzieci i młodzieży. Analiza kliniczna, Psychiatria Polska, 1-2 (16), 25-30.

Bomba, J. (2007). Depresja młodzieńcza, (w:) I. Namysłowska (red.), Psychiatria dzieci i młodzieży, 363-378, Warszawa: Wydawnictwo Lekarskie PZWL.

Bomba, J., Modrzewska, M. (2006). Prospektywne badanie depresji u młodzieży w fazie dorastania, Psychiatria Polska, 4, 683-693.

Bomba, J. (2009). Spojrzenie na depresję z perspektywy psychoterapii, Psychoterapia, 1 (148), $35-42$.

Colom, F. (2011). Keeping therapies simple: psychoeducation in the prevention of relapse in affective disorders, The British Journal of Psychiatry, 5 (198), 338-340, doi: https://doi.org/10.1192/bjp.bp.110.090209.

Grabski, B., Mączka, G., Dudek, D. (2007). The role of psychoeducation in the complex treatment of bipolar disorder, Archives of Psychiatry and Psychotherapy, 3, 35-41.

Hammen, C. (2006). Depresja, Gdańsk: Gdańskie Wydawnictwo Psychologiczne.

Januszewska, E. (2020). Depresja, osamotnienie a przeżyta trauma u dzieci, (w:) E. Chodźko, K. Talarek (red.), Wyzwania i problemy społeczeństwa w XXI wieku, tom I, 97-117, Lublin: Wydawnictwo Naukowe TYGIEL

Kalinowska, S., Nitsch, K., Duda, P., Trześnikowska-Drukała, B., Samachowiec, J. (2013). Depresja u dzieci i młodzieży - obraz kliniczny, etiologia, terapia, Analles Academiae Medicae Steinenis - Roczniki Pomorskiej Akademii Medycznej w Szczecinie, 1 (59), 26-32.

Kępiński, A. (2014). Melancholia, Kraków: Wydawnictwo PWN.

Kołodziejek, M. (2008). Depresja u dzieci i młodzieży: podstawy teoretyczne, psychoterapia poznawczo behawioralna, Psychoterapia, 2 (145), 15-33.

Krupa, B. (2013). Samotność - znak czasu, (w:) Z.B. Gaś (red.), Człowiek na rozdrożu. Zrozumieć, aby pomóc, 95-112, Lublin: Wydawnictwo Naukowe Innovatio Press.

McCauley, E., Pavlidis, K., Kendall, K. (2001). Developmental precursors of depression: the child and the social environment, (in:) I.M. Goodyer (ed.), The depressed child and adolescent, 46-78, Cambridge: Cambridge University Press.

Michalska-Leśniewicz, M., Gruszczyński, W. (2010). Czynniki psychologiczne w depresji, Psychiatria, 3 (7), 95-103. 
Modrzejewska, R., Bomba, J. (2006a). Porównanie rozpowszechnienia depresji w populacji 13-letniej młodzieży krakowskich szkół średnich w latach 1984-2001, Psychiatria Polska, 3, 469-479.

Modrzejewska, R., Bomba, J. (2006b). Porównanie rozpowszechnienia depresji w populacji 10-letnich dzieci krakowskich szkół podstawowych w latach 1984 i 2001, Psychiatria Polska, 3, 1118-1128.

Modrzejewska R., Bomba J. (2010). A comparative study of adolescent depression among high school pupils in a large Polish city, Archives of Psychiatry and Psychotherapy, 2, 17 22.

Przybylska, K. (2016). Depresja chorobą cywilizacyjną XXI wieku - leczenie farmakologiczne a psychoterapia, (w:) M. Maciąg, B.A. Nowak (red.), Choroby cywilizacyjne i społeczne XXI w. - przeglad i badania, 136-143, Lublin: Wydawnictwo Naukowe TYGIEL

Raczkowski, A. (2017). Depresja dzieci i młodzieży - zjawisko i perspektywa pomocy, Wychowanie w rodzinie XIV, 2, 315-329, doi: https://doi.org/10.23734/wwr20172.315.329.

Rabe-Jabłońska, J. (2007). Zaburzenia afektywne u dzieci i młodzieży, (w:) I. Namysłowska (red.), Psychiatria dzieci i młodzieży, 363-378, Warszawa: Wydawnictwo Lekarskie PZWL.

Radziwiłłowicz, W. (2010). Depresja u dzieci i młodzieży. Analiza systemu rodzinnego, ujęcie kliniczne, Kraków: Oficyna Wydawnicza „Impuls”.

Ryś, M. (2020). Poczucie osamotnienia jako symptom naszych czasów (w:) Z.B. Gaś (red.), Mistrzowie psychologii wobec wyzwań wspótczesności, 17-51, Lublin: Wydawnictwo Innovatio Press.

Tomaszewska, H. (2012). Młodzież rówieśnicy i nowe media. Społeczne funkcje technologii komunikacyjnych w życiu nastolatków, Warszawa: Wydawnictwo Akademickie Żak.

Segal, H. (2005). Wprowadzenie do teorii przywiazania Melanie Klein, Gdańsk: Gdańskie Wydawnictwo Psychologiczne.

Sęk, H. (2008). Psychologia kliniczna, tom 1, Warszawa: Wydawnictwo Naukowe PWN.

Sikorska, I. (2016). Odporność psychiczna w okresie dzieciństwa, Kraków: Wydawnictwo Uniwersytetu Jagiellońskiego.

Stallard, P. (2008). Czujesz tak, jak myślisz. Praktyczne zastosowania terapii poznawczobehawioralnej w pracy z dziećmi i młodzieżą, Poznań: Zysk i S-ka.

Wendołowska, A. (2017). Depresja adolescentów w świetle teorii przywiązania, Psychoterapia, 2 (181), 87-102. 